\title{
Molecular Docking, Synthesis, in Silico and in vitro Screening of Substituted Aryl Ureido Analogues as BACE1 Inhibitors to target Alzheimer's Disease
}

\author{
Archana S Gurjar*1, Vinay Velingkar ${ }^{2}$, Vincenza Andrisano ${ }^{3}$ and Angela D Simone ${ }^{3}$ \\ ${ }^{1}$ Department of Pharmaceutical Chemistry, India \\ ${ }^{2}$ HK College of Pharmacy, India \\ ${ }^{3}$ Department for Life Quality Studies, India
}

Received: 眥: November 16, 2018; Published: 制: December 04, 2018

*Corresponding author: Archana S Gurjar, Department of Pharmaceutical Chemistry, Prin KM Kundnani College of Pharmacy, 23 Jote Joy, R. S. Marg, Cuffe Parade, Mumbai, 400 005, India

\begin{abstract}
BACE1 plays critical role in the formation of neurotoxic $\beta$-amyloid $(A \beta)$ peptides in brain and so is regarded as an ideal drug design target for Alzheimer's disease. With this perspective, we have designed BACE1 inhibitors, specifically substituted aryl ureido analogues. Docking studies revealed interactions with the crucial catalytic Aspartate dyad of BACE1 enzyme. In silico ADME studies predicted favourable drug like properties for these analogues. Molecular docking results were in consensus with the pharmacological screening of the synthesized analogues. Overall results indicate that analogue $4 \mathrm{c}$ and $4 \mathrm{~d}$ exhibit equivalent BACE1 enzyme inhibition.
\end{abstract}

Keywords: BACE1; Aryl Ureido Analogues; Molecular Docking; in Silico ADME; In Vitro; FRET Assay

\section{Introduction}

In Alzheimer's disease, one of the defining crucial hallmark in brain is the formation of extracellular amyloid-beta $(A \beta)$ peptide plaques and the other being intracellular aggregation of hyper phosphorylated tau to form neurofibrillary tangles. Literature directs, cerebral $A \beta$ accumulation begins at an earlier stage i.e. 10-20 years before the inception of dementia, which indicates that targeting $A \beta$ deposition in brain will be apt for $A D$ pathogenesis [1]. BACE1 ( $\beta$-site APP cleaving enzyme, $\beta$-secretase) is the first protease of the amyloid cascade which initiates cleavage of the amyloid precursor protein (APP) to generate two fragments viz. $\mathrm{N}$ terminal fragment and a $\mathrm{A} \beta$-containing $\mathrm{C}$-terminal fragment. Subsequently, the $\mathrm{C}$-terminal fragment is cleaved by $\gamma$-secretase to liberate $A \beta$ peptides (A $\beta 40$ or $A \beta 42)$ and an APP intracellular domain (AICD). In $A D, A \beta 42$ is over produced due to genetic mutations of either the APP gene or other genes. The A $\beta 42$ peptide is more hydrophobic and stickier than $A \beta 40$ so it readily clumps resulting in formation of amyloid plaques [2,3].
As BACE1 is the key rate limiting enzyme of the amyloidogenic pathway so, inhibition of $\beta$-secretase can be considered as a prominent therapeutic target for treatment of $\mathrm{AD}$ as the disease still lacks an effective treatment [4-6]. BACE1 is highly expressed in brain and belongs to aspartyl protease family [7]. Literature survey indicates that the active site of BACE1 has two catalytic aspartic residues (Asp32 and Asp228),[8] optimum acidic pH and the correct sequence specificity for enzymatic activity [5]. The reported crystal structure of BACE1 complexed with OM00-3, an octapeptide inhibitor (PDB: 1m4h); depicts eight sub sites for ligand-enzyme interaction [9]. Literature reports discovery of many peptidomimetic as well as non-peptide BACE1 inhibitors [10,11]. Although, peptidomimetic inhibitors displayed potent activity against BACE1, their relatively large molecular size, low metabolic stability and poor bioavailability rendered their development into therapeutic drug candidates difficult [12]. Hence, now the research interest are directed more towards development of small nonpeptide organic moieties as lead compounds [13-16]. 
Some notable small-molecule nonpeptide BACE1 inhibitor classes are Vertex biarylnaphthalenes. acylcarbinamine, acylguanidine, aminothiazines, and aminoquinazoline-based scaffolds [6]. Huang and co-workers have reported their work on cell permeable diphenyl urea analogues [17]. Zhu et al revealed unique interaction pattern of CNS penetrant amidine containing heterocylic analogues with BACE1 catalytic dyad [18]. Prompted by above findings we tried to explore the possibility of substituted aryl groups on the two amidine nitrogen's and replacement of one of the nitrogen with oxygen to simulate ureido functionality. By this approach we designed, synthesized and screened substituted aryl ureido analogues (1) derived from substituted anthranilic acid as potential non-peptide BACE1 inhibitors. In silico ADME studies were carried out to evaluate drug like properties of the candidates (Figure 1).

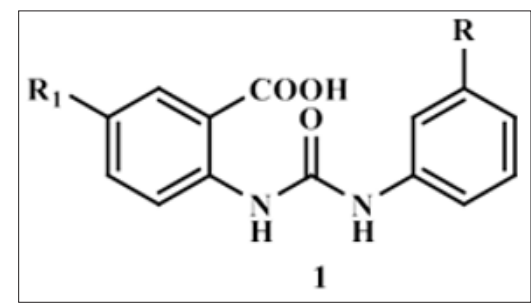

Figure 1: Substituted phenyl ureido benzoic acid scaffold.

\section{Results and Discussion}

\section{Molecular Docking}

Docking approach was employed to explore the BACE1 active site and to estimate binding interactions of these analogues with the receptor. For docking studies, the protein data bank (PDB: $1 \mathrm{~m} 4 \mathrm{~h}$ ) crystal structure of BACE1 complexed with OM00-3 inhibitor possessing good potency (Ki: $0.3 \mathrm{nM}$ ) was considered. This inhibitor exhibits significant binding to the sub sites and has been extensively studied [19]. The docking protocol was validated by reproduction of binding pose of OM00-3 inhibitor in the $1 \mathrm{~m} 4 \mathrm{~h}$ active site (rmsd 1.51). The octapeptide inhibitor OM00-3 of PDB $1 \mathrm{~m} 4 \mathrm{~h}$ occupies S1, S2, S1' and S2' sub sites. To judge further, some reported non-peptide BACE1 inhibitors were docked in the BACE1 active site. Many exhibited interactions with the crucial catalytic dyad involved in drug-receptor binding and enzymatic catalysis. They occupied S1, S2 and S1' sub sites in the active site [20]. As per the Hong et al amino acid residues present in various sub sites were: S1- Leu30, Asp32, Tyr71, Gln73, Phe108, Asp228, Gly230; S2- of Tyr71, Thr72, Gln73, Gly230, Thr231, Arg235 residues and S1'- Gly34, Tyr71, Thr232 and Arg307 [9]. On the same guidelines, series of 2-(3-substitutedphenylureido)-5-nitrobenzoic acids (Type I) was docked in the BACE1 active site (Table 1).

Table 1: SAR of 2-(3'-(3"-substitutedphenyl)ureido)-5-nitrobenzoic acids.

\begin{tabular}{|c|c|c|c|c|c|c|c|c|}
\hline Compd & $\mathbf{R}$ & MW [d] & $\begin{array}{c}\mathrm{QP} \\
\log \mathrm{Po} / \mathrm{w}\end{array}$ & HBD & QP $\log B B$ & SASA ${ }^{[\mathrm{e}]}$ & \% Human Oral Absorption & $\%$ inhibition \pm SD at $50 \mu \mathrm{M}[\mathrm{f}]$ \\
\hline $4 a$ & COMe & 343 & 1.27 & 2 & -2.71 & 610 & 43 & $36.51 \pm 4.15$ \\
\hline $4 \mathrm{~b}$ & $\mathrm{Cl}$ & 336 & 2.21 & 2 & -1.91 & 572 & 57 & $25.54 \pm 7.83$ \\
\hline $4 \mathrm{c}$ & $\mathrm{CN}$ & 326 & 1.01 & 2 & -2.92 & 587 & 38 & $39.39 \pm 1.91$ \\
\hline $4 d$ & $\mathrm{OMe}$ & 331 & 1.85 & 2 & -2.12 & 583 & 55 & $38.58 \pm 1.70$ \\
\hline $4 e$ & $\mathrm{SMe}$ & 347 & 2.37 & 2 & -2.04 & 607 & 59 & $20.43 \pm 9.35$ \\
\hline $4 \mathrm{f}$ & NO2 & 346 & 1.04 & 2 & -3.14 & 586 & 20 & $27.53 \pm 7.24$ \\
\hline
\end{tabular}

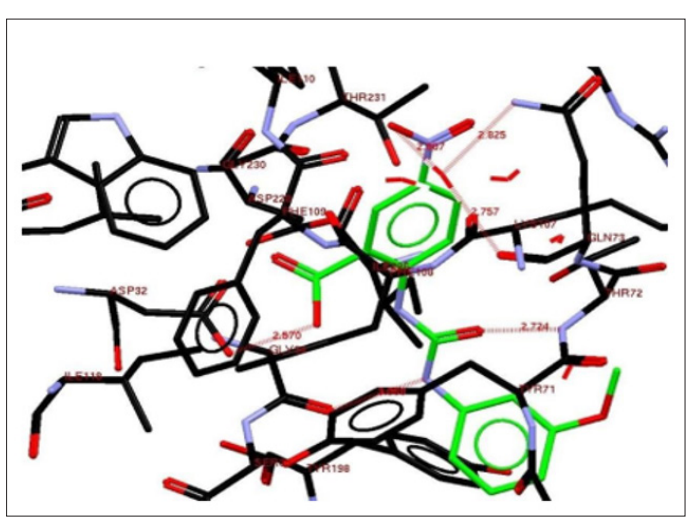

Figure 2: Docking pose of 2-(3'-(3"-methoxyphenyl) ureido)-5-nitrobenzoic acid (4d) in BACE1 active site.
These analogues were found to be oriented in the centre of BACE1 binding pocket, occupying S1, S2 and S1' sub sites analogous to the reported docked inhibitors. In Type I series, the 5-nitro group in all analogues exhibited bidentate interactions (H-bond and electrostatic) with Gln73 residue through water molecule except 4c wherein the nitro group interacted with Thr72. Interestingly, in 4c both the ureido nitrogen's formed H-bonds with the catalytic residue Asp32 of BACE1. In the other Type I analogues, apart from the nitro group, ureido as well the carboxylic acid group depicted interactions with BACE1. Like reported inhibitors, they were associated with Asp32, Gly34, Thr72 and Gly230 residues of BACE1 active site. These findings were similar to the reported motifs so it can be envisaged that these 2-(3'-(3"-substitutedphenyl)ureido)-5-nitrobenzoic acids successfully bind to the BACE1 catalytic site and should therefore turn out to be fruitful candidates for BACE1 inhibition (Figure 2). 
Further, to study the effect of introduction of basic group on interaction pattern of Type I series within BACE1 active site, the acidic nitro group was replaced by amino group to obtain a new series of 5-(3'-(3"-substitutedphenyl)ureido)-2-aminobenzoic acids (Type II) (Table 2). These analogues occupied S1 and S1' sub sites. Analogous to 4c, nitrogens of the ureido group of all analogues of this new series depicted bidentate interaction with Asp32 via $\mathrm{H}$-bond and electrostatic interactions except $5 \mathrm{f}$ whose ureido group interactions where similar to other Type I members. The newly introduced 2-amino group formed H-bonds either directly or through water molecule with Lys107 and Phe108 residues, which was different from Type I series ligands. On superimposing these Type II analogues with the Type I ligands, orientation of both the series was found to be different which may account for change in the interaction pattern within BACE1 active site (Figure 3).

Table 2: SAR of 5-(3'-(3"-substitutedphenyl)ureido)-2-aminobenzoic acids.

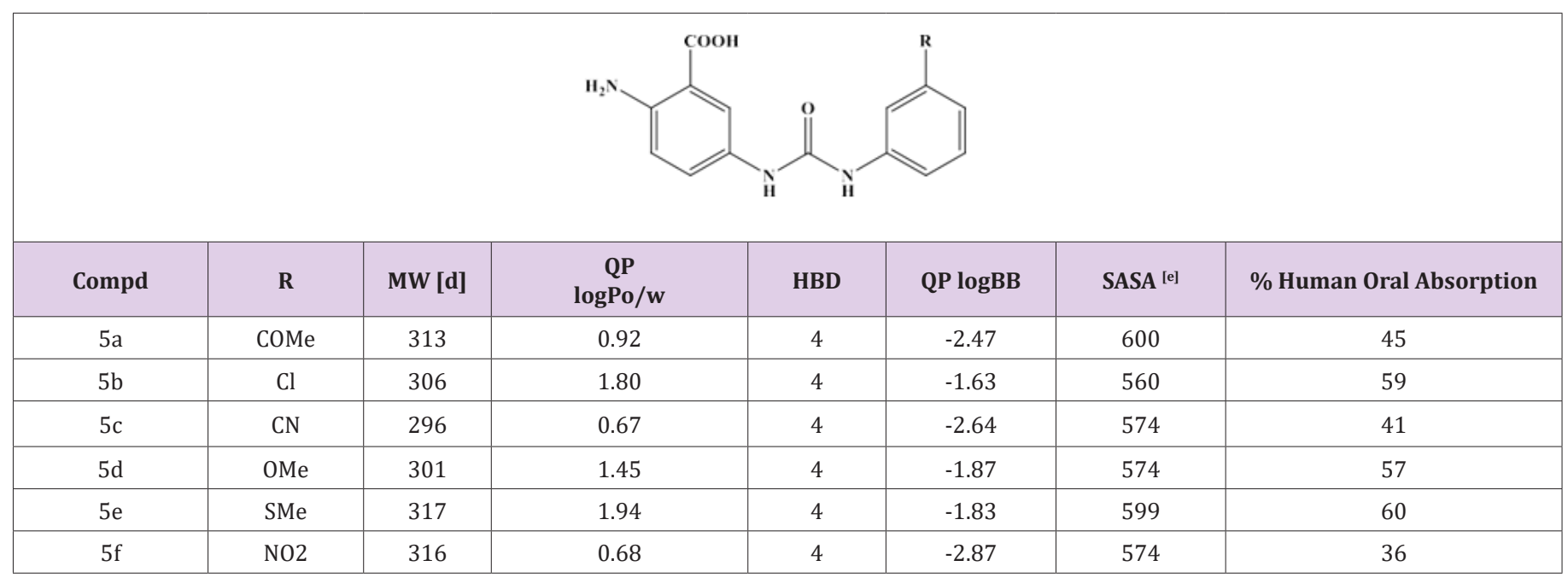

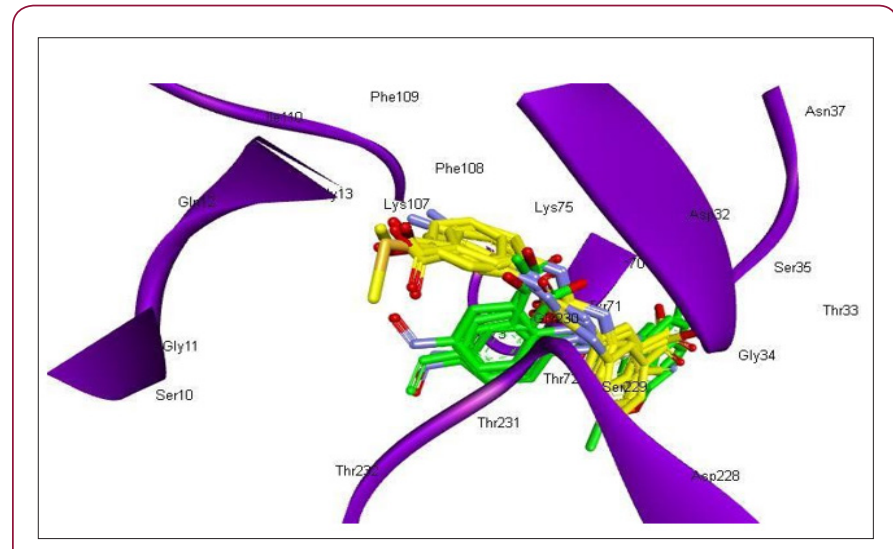

Figure 3: Orientation of Substituted Aryl Ureido Analogues in BACE1 active site [a]. Note:

[a] Blue coloured solid ribbon denotes BACE1 active site residues. Type I shown in green colour and Type II depicted by yellow colour.

\section{In Silico ADME Studies}

The in silico ADME (Absorption, Distribution, Metabolism and Excretion) properties of designed test set analogues and reported ones were determined to gain an understanding of their pharmacokinetic behavior invivo. The 2-(3'-(3"-substitutedphenyl)ureido)-5nitrobenzoic acids (Table 1) possessed descriptor values within the recommended range of QikProp software such as low molecular weight ( $\mathrm{MW}<350 \mathrm{~g} / \mathrm{mol}$ ), hydrogen bond donor (HBD) $<3$ and QP $\operatorname{logPo} / \mathrm{w}$ values in the range of 1.0-2.4 [21]. Bioavailability can be gauged by estimating the QP $\log$ P values, literature states that for therapeutic use, compounds with QP $\log$ P values lower than 5 may have improved drug properties compared to more hydrophobic analogues [22]. The QP $\log$ P values for these analogues appear to be favourable. Ghose et al has mentioned some guidelines to design good quality CNS drugs: favorable QikProp CNS parameter, total solvent accessible surface area (SASA) of 460-580 ̊̊2 and HBD less than 3 [23]. For permeability through the blood brain barrier (BBB), QikProp predicts QP $\log B B$; the brain-blood partition coefficient. The QP $\operatorname{logBB}$ values were obtained in range of -1.9 to -2.7 (Expected range: $-3-1.2$ ) except $4 \mathrm{f}$ analogue.

Similarly, the SASA values were found to be in the range of 572610 , very much favourable to be the likely CNS candidates. Series of 5-(3'-(3"-substitutedphenyl)ureido)-2-aminobenzoic acids (Table 2) exhibited some values similar to Type I series such as low molecular weight (MW $<320 \mathrm{~g} / \mathrm{mol}$ ). Comparison of QP $\operatorname{logPo} / \mathrm{w}$ values (0.5-2.0) with Type I analogues indicated that they are less hydrophobic and HBD value was 4, well within QikProp limit but a digit more than the limit specified by Ghose et al. SASA values were observed to be in between 574-600, seems to be favourable. QP $\operatorname{logBB}$ values were observed in the expected range to be-1.6 to -2.9. The percent Human oral absorption for both the series were found to be moderate i.e. $40-60 \%$. None of them violated the Lipinski's rule of five. 


\section{Synthesis}

The Type I series docking results were analogous to reported ones so the analogues were synthesized and the structures were confirmed by use of spectral techniques (Scheme 1). In addition, the in silico ADME results were more favourable for the Type I analogues. Further, they were subjected to screening for activity against BACE1.

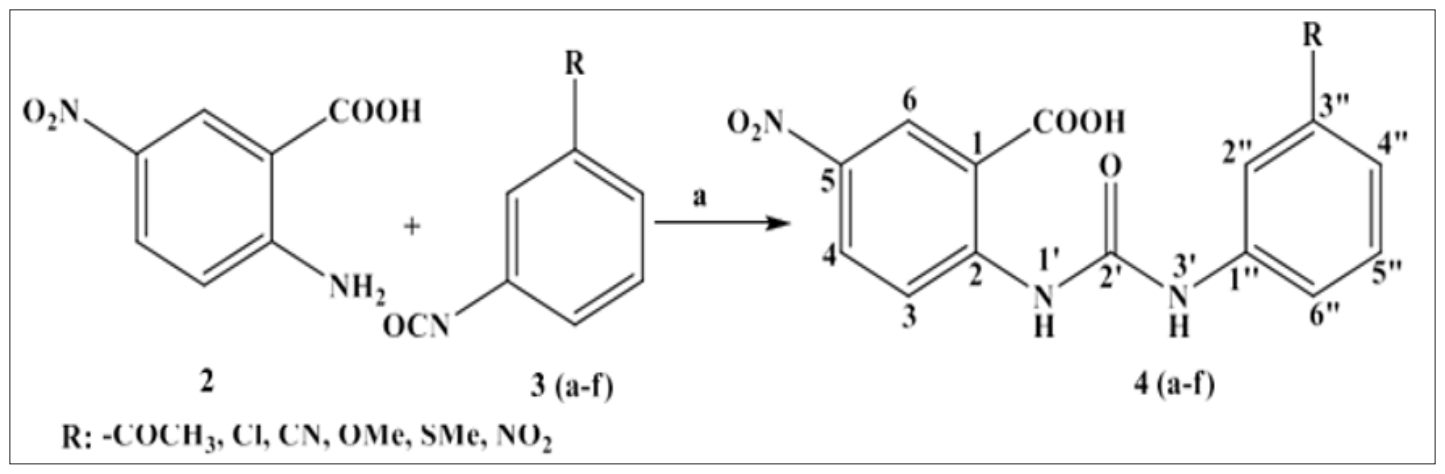

Scheme 1: [a] Reagents: (a) Acetone, 40oC.

\section{Pharmacological screening}

The in vitro BACE1 FRET (Fluorescence resonance energy transfer) inhibition study results were in agreement to the molecular docking outcome. All analogues of the series 2-(3'-(3"-substitutedphenyl)ureido)-5-nitrobenzoic acids showed BACE1 enzyme inhibition at $50 \mu \mathrm{M}$ concentration (Table 1). The percent inhibition at $50 \mu \mathrm{M}$ concentration was found to be in the range of $20-40 \%$.

\section{Conclusion}

The intention to design this scaffold was to analyse the suitability of carboxylic acid group possessing compounds as prospective CNS candidates; as literature indicates that carboxylic acid group is not a very common functionality in the design of CNS drugs. It has been observed that many non-CNS drugs especially orally administered ones have carboxylic acid group while very few CNS drugs possess it. Only 3-4\% of CNS drugs had a carboxylic acid group, whereas $25 \%$ of non-CNS oral drugs possessed a carboxylic acid group. The docking and in vitro screening studies comply with our assumptions that the substituted aryl ureido analogues can be targeted for potential CNS use. Comparison between the two serie projects the 2-(3'-(3' substitutedphenyl)ureido)-5-nitrobenzoic acids (Type I) to be more suitable candidates than Type II series. Amongst them the $4 \mathrm{c}$ and $4 \mathrm{~d}$ analogues exhibit equivalent BACE1 enzyme inhibition. These analogues can be further optimized by suitable structural modifications to attain a more targeted concentration at the site for higher favourable response as BACE1 inhibitors.

\section{Experimental Section}

\section{Molecular Docking}

Materials: On Red Hat Enterprise Linux (RHEL) workstation various software's viz. Sybyl version 8.1.1 (Tripos International, Portugal) [24] and GOLD version 4.1.1 (CCDC Ltd., UK) [25] were utilized for ligand as well as protein preparation and docking studies. Designing of ligands and protein preparation. The method already reported in our publication was followed for ligand and protein preparation. The same protein data bank crystal structure (PDB code 1 $\mathrm{m} 4 \mathrm{~h}$ ) in which BACE1 is complexed with an octapeptide OM00-3 was prepared and further considered for docking studies [26].

Designing of ligands and protein preparation: The method already reported in our publication was followed for ligand and protein preparation. The same protein data bank crystal structure (PDB code 1m4h) in which BACE1 is complexed with an octapeptide OM00-3 was prepared and further considered for docking studies [26].

Docking protocol: The earlier published protocol was followed for docking studies of these analogues [26].

\section{In silico ADME studies}

Materials: For the studies Qik Prop version 3.0 (Schrodinger LLC, New York, USA) software on

RHEL workstation was employed [21].

Method: Same method as followed in our earlier work was utilized to determine various descriptor values for the in silico ADME studies [26].

\section{Synthesis}

Materials: As per the requirement solvent used were distilled for purification purpose. Merck

F254 TLC plates were used to monitor progress of reaction. The title compounds were purified using recrystallization and/ or column chromatographic technique. Infrared (IR) spectra were recorded on Shimadzu IR Affinity-1 FTIR spectrophotometer using DRS-8000 (Diffuse Reflectance attachment). 1HNMR spectra and Mass spectra have been recorded on Mercury Plus $300 \mathrm{MHz}$ (Varian, USA) NMR spectrometer and 410 Prostar Binary LC with 500 MS IT PDA detectors (Varian Inc, USA) mass spectrometer respectively. 
For 1HNMR spectra tetramethylsilane (TMS) has been used as an internal standard and DMSO-d6 (Dimethyl sulfoxide) as solvent.

2-(3'-(3"-Substitutedphenyl)Ureido)-5-Nitrobenzoic Acids (4 (a-f)): The 2-(3'-(3"-substitutedphenyl)ureido)-5-nitrobenzoic acids were synthesized as per Scheme 1 .

General Method for Analogues (4 (a-f)): To the solution of 2-amino-5-nitrobenzoic acid (2, $0.2 \mathrm{~g}, 1.0989 \mathrm{mmol}$ ) in $2 \mathrm{ml}$ dry acetone, equimolar solution of respective 3-substitutedphenyl isocyanate ( 3 (a-f) ) in $2 \mathrm{ml}$ dry acetone was added gradually at $40 \mathrm{oC}$ in $15-20$ minutes with stirring. The reaction mixture was refluxed at $40 \mathrm{oC}$ for 16 hours with addition of minimum amount of dry acetone if needed. Further, mixture was poured in $50 \mathrm{ml}$ water for precipitation of crude product which was recrystallized from ethanol resulting in pure analogues as product (5 (a-f)) [27].

2-(3'-(3"-acetylphenyl)ureido)-5-nitrobenzoic acid (5a): Yield: 64\%; 206-08oC. IR (KBr) v: 1708 (ureido), 3089 (C-H), 1695 (>C=0), 1593, 1357 (NO2), 1681 (COCH3) cm-1. 1HNMR (DMSO-d6): $\delta 10.60(\mathrm{~s}, 1 \mathrm{H}), 10.28(\mathrm{~s}, 1 \mathrm{H}), 9.33(\mathrm{~s}, 1 \mathrm{H}), 8.19(\mathrm{~d}, 1 \mathrm{H}$, $\mathrm{J}=8.8 \mathrm{~Hz}), 8.12(\mathrm{t}, 1 \mathrm{H}, \mathrm{J}=1.6 \mathrm{~Hz}), 7.90(\mathrm{~d}, 1 \mathrm{H}, \mathrm{J}=8.8 \mathrm{~Hz}), 7.85(\mathrm{~d}$,

$1 \mathrm{H}, \mathrm{J}=2.6 \mathrm{~Hz}), 7.82(\mathrm{td}, 1 \mathrm{H}, \mathrm{J}=6.6,2.3 \mathrm{~Hz}), 7.63(\mathrm{dd}, 1 \mathrm{H}, \mathrm{J}=5.3$, $2.4 \mathrm{~Hz}$ ), 7.47 (t, 1H, J = 7.9 Hz), 2.57 (s, 3H). MS (acetone) [M]: 342.

2-(3'-(3"-Chlorophenyl)Ureido)-5-Nitrobenzoic Acid (5b): Yield: 73\%; 218oC. IR (KBr) v: 1720 (ureido), 3035 (C-H), 1691 (>C=0), 1597, 1355 (NO2) cm-1. 1HNMR (DMSO-d6): $\delta 10.60$ (s, 1H), 10.25 (s, 1H), 9.31 (s, 1H), 8.19 (d, 1H, J =8.8 Hz), 7.86 (d, 1H, J $=2.2 \mathrm{~Hz}), 7.83(\mathrm{~d}, 1 \mathrm{H}, \mathrm{J}=2.2 \mathrm{~Hz}), 7.75(\mathrm{t}, 1 \mathrm{H}, \mathrm{J}=2.0 \mathrm{~Hz}), 7.40(\mathrm{td}, 1 \mathrm{H}$, $\mathrm{J}=8.2,1.6 \mathrm{~Hz}), 7.33(\mathrm{t}, 1 \mathrm{H}, \mathrm{J}=7.9 \mathrm{~Hz}), 7.08(\mathrm{td}, 1 \mathrm{H}, \mathrm{J}=5.7,1.7 \mathrm{~Hz})$. MS (acetone) [M]: 334 .

2-(3'-(3"-Cyanophenyl)Ureido)-5-Nitrobenzoic Acid (5c): Yield: 36\%; 208oC. IR (KBr) v: 1708 (ureido), 3055 (C-H), 1697 (>C=0), 1591, 1346 (NO2), 2249 (CN) cm-1. 1HNMR (DMSO-d6): $\delta$ $10.65(\mathrm{~s}, 1 \mathrm{H}), 10.40(\mathrm{~s}, 1 \mathrm{H}), 9.30(\mathrm{~s}, 1 \mathrm{H}), 8.19(\mathrm{~d}, 1 \mathrm{H}, \mathrm{J}=8.8 \mathrm{~Hz}), 8.00$ $(\mathrm{t}, 1 \mathrm{H}, \mathrm{J}=6.6 \mathrm{~Hz}), 7.91(\mathrm{~d}, 1 \mathrm{H}, \mathrm{J}=8.8 \mathrm{~Hz}), 7.85(\mathrm{~d}, 1 \mathrm{H}, \mathrm{J}=2.2 \mathrm{~Hz}), 7.75$ (d, $1 \mathrm{H}, \mathrm{J}=8.1 \mathrm{~Hz}), 7.63(\mathrm{~d}, 1 \mathrm{H}, \mathrm{J}=2.2 \mathrm{~Hz}), 7.48(\mathrm{t}, 1 \mathrm{H}, \mathrm{J}=6.2 \mathrm{~Hz}) . \mathrm{MS}$ (acetone) [M]: 325 .

2-(3'-(3"-Methoxyphenyl)Ureido)-5-Nitrobenzoic Acid (5d): Yield: 63\%; 198oC. IR (KBr) v: 1724 (ureido), 3034 (C-H), 1697 (>C=0), 1598, 1359 (NO2), 2843 (OCH3) cm-1. 1HNMR (DMSO-d6): $\delta 10.51(\mathrm{~s}, 1 \mathrm{H}), 10.04(\mathrm{~s}, 1 \mathrm{H}), 9.31(\mathrm{~s}, 1 \mathrm{H}), 8.18(\mathrm{~d}, 1 \mathrm{H}, \mathrm{J}=$ $8.4 \mathrm{~Hz}$ ), 7.83 (dd, $1 \mathrm{H}, \mathrm{J}=8.8,2.6 \mathrm{~Hz}), 7.22(\mathrm{t}, 1 \mathrm{H}, \mathrm{J}=2.2 \mathrm{~Hz}), 7.21(\mathrm{~d}$, $1 \mathrm{H}, \mathrm{J}=1.1 \mathrm{~Hz}), 7.17(\mathrm{~d}, 1 \mathrm{H}, \mathrm{J}=6.2 \mathrm{~Hz}), 7.08(\mathrm{td}, 1 \mathrm{H}, \mathrm{J}=8.1,1.1 \mathrm{~Hz})$, $6.61(\mathrm{td}, 1 \mathrm{H}, \mathrm{J}=8.1,2.7 \mathrm{~Hz}), 3.74$ (s, 3H). MS (acetone) [M]: 330.

2-(3'-(3"-Methylthiophenyl)Ureido)-5-Nitrobenzoic Acid (5e): Yield: 63\%; 184-186oC. IR (KBr) v: 1720 (ureido), 3082 (CH), 1697 (>C=0), 1585, 1357 (NO2), 678 (SCH3) cm-1. 1HNMR (DMSO-d6): $\delta 10.54(\mathrm{~s}, 1 \mathrm{H}), 10.07(\mathrm{~s}, 1 \mathrm{H}), 9.31(\mathrm{~s}, 1 \mathrm{H}), 8.18(\mathrm{~d}, 1 \mathrm{H}$, $\mathrm{J}=8.8 \mathrm{~Hz}$ ), $7.83(\mathrm{dd}, 1 \mathrm{H}, \mathrm{J}=8.6,2.4 \mathrm{~Hz}), 7.50(\mathrm{t}, 1 \mathrm{H}, \mathrm{J}=1.8 \mathrm{~Hz}), 7.30$ $(\mathrm{d}, 1 \mathrm{H}, \mathrm{J}=1.8 \mathrm{~Hz}), 7.28(\mathrm{t}, 1 \mathrm{H}, \mathrm{J}=5.1 \mathrm{~Hz}), 7.25(\mathrm{dd}, 1 \mathrm{H}, \mathrm{J}=8.2,3.5$ $\mathrm{Hz}), 6.91(\mathrm{td}, 1 \mathrm{H}, \mathrm{J}=7.3,1.5 \mathrm{~Hz}), 2.47$ (s, 3H). MS (acetone) [M]: 346.
2-(3'-(3"-Nitrophenyl)Ureido)-5-Nitrobenzoic Acid (5f): Yield: 74\%; 202oC. IR (KBr) v: 1720 (ureido), 3088 (C-H), 1703 $(>\mathrm{C}=0$ ) $, 1602,1354$ (NO2) cm-1. 1HNMR (DMSO-d6): $\delta 10.70$ (s, $1 \mathrm{H}), 10.57$ (s, 1H), 9.32 (s, 1H), 8.56 (t, 1H, J =2.0 Hz), 8.19 (d, 1H, J $=8.8 \mathrm{~Hz}), 7.88(\mathrm{~d}, 1 \mathrm{H}, \mathrm{J}=2.9 \mathrm{~Hz}), 7.85(\mathrm{dd}, 1 \mathrm{H}, \mathrm{J}=6.0,2.7 \mathrm{~Hz}), 7.62$ $(\mathrm{t}, 1 \mathrm{H}, \mathrm{J}=3.1 \mathrm{~Hz}), 7.59(\mathrm{~d}, 1 \mathrm{H}, \mathrm{J}=7.3 \mathrm{~Hz}), 7.56(\mathrm{~d}, 1 \mathrm{H}, \mathrm{J}=3.7 \mathrm{~Hz}) . \mathrm{MS}$ (acetone) [M]: 345.

\section{Pharmacological Screening}

Materials: BACE1 FRET (Fluorescence resonance energy transfer) inhibition study was performed by Department of Pharmaceutical Sciences, University of Bologna, Italy, by the M-2420 method [7,28].

Preliminary Screening: Similar procedure as reported in our earlier published work was followed for the BACE1 inhibition study using the same M-2420 method [26].

\section{Acknowledgment}

We acknowledge the University Grants Commission (UGC), New Delhi for sanction of Major Research Project grant (F: 34126/2008(SR) dated: 29th December'2008).

\section{References}

1. Vassar R (2014) BACE1 inhibitor drugs in clinical trials for Alzheimer's disease. Alzheimer's Research \& Therapy 6(9): 89.

2. Schmid B, Baumann S, Narlawar R, Braun HA, Larbig G Neurodegener (2006) Modulators and Inhibitors of $\gamma$ - and $\beta$-Secretases. Dis 3(4-5): 290.

3. Cavalli A, Bolognesi ML, Minarini A, Rosini M, Tumiatti V, et al. (2008) Multi-target-directed ligands to combat neurodegenerative diseases. Journal of Medicinal Chemistry 51(3): 347-372.

4. Ghosh AK, Osswald HL (2014) BACE1 ( $\beta$-secretase) inhibitors for the treatment of Alzheimer's disease Chem Soc Rev 43(19): 6765.

5. Yan R, Vassar R (2014) Targeting the $\beta$ secretase BACE1 for Alzheimer's disease therapy. The Lancet Neurology 13(3): 319-329.

6. Ghosh AK, Tang J (2015) Prospects of $\beta$-Secretase Inhibitors for the Treatment of Alzheimer's Disease. Chem Med Chem 10(9): 1463-1466.

7. Mancini F, De Simone A, Andrisano V (2011) Beta-secretase as a target for Alzheimer's disease drug discovery: an overview of in vitro methods for characterization of inhibitors. Analytical and Bioanalytical Chemistry 400(7): 1979-1996.

8. Malamas MS, Erdei J, Gunawan I, Turner J, Hu Y, et al. (2010) Design and Synthesis of 5,5-Disubstituted Aminohydantoins as Potent and Selective Human $\beta$-Secretase (BACE1) Inhibitors J Med Chem ACS 53: 1146-1158.

9. Hong L, Turner RT, Koelsch G, Shin D, Ghosh AK, Tang (2002) Crystal structure of memapsin 2 (beta-secretase) in complex with an inhibitor OM00-3. J Biochemistry 41(36): 10963-10967.

10. Schmidt B, Braun HA, Narlawar R (2005) Drug development and PETdiagnostics for Alzheimer's disease. Cur Med Chem 12(14): 1677.

11. Huang WH, Sheng R, Hu YZ (2009) Progress in the development of nonpeptidomimetic BACE-1 inhibitors for Alzheimer's disease. Cur Med Chem 16(14): 1806-1820.

12. Gutierrez LJ, Enriz RD, Baldoni HA (2010) Structural and thermodynamic characteristics of the exosite binding pocket on the human BACE1: a molecular modeling approach. J Phys Chem A 114(37): 10261. 
13. John V, Beck JP, Bienkowski MJ, Sinha S, Heinrikson RL (2003) Human $\beta$-Secretase (BACE) and BACE Inhibitors. Journal of Medicinal Chemistry 46(22): 4625-4630.

14. Jeppsson F, Eketjall S, Janson J, Karlstrom S, Gustavsson S, et al. (2012) Discovery of AZD3839, a potent and selective BACE1 inhibitor clinical candidate for the treatment of Alzheimer disease. J Biol Chem 287(49): 41245 .

15. Tseng J, Dockendorf M, Krishna G, Ma L, Palcza J, et al. (2012) Safety and pharmacokinetics of the novel BACE inhibitor MK-8931 in healthy subjects following single- and Multiple-Dose administration. Alzheimer's \& Dementia 8(4): 184.

16. Yuan J, Venkatraman S, Zheng Y, Mc Keever BM, Dillard LW, et al. (2013) Structure-based design of $\beta$-site APP cleaving enzyme 1 (BACE1) inhibitors for the treatment of Alzheimer's disease. J Med Chem 56(11): 4156.

17. Huang D, Lüthi U, Kolb P, Edler K, Cecchini M, et al. (2005) Discovery of Cell-Permeable Non-Peptide Inhibitors of $\beta$-Secretase by HighThroughput Docking and Continuum Electrostatics Calculations. J Med Chem 48(16): 5108-5111.

18. Zhu Z, Sun ZY, Ye Y, Voigt J, Strickland C, et al. (2010) Discovery of Cyclic Acylguanidines as Highly Potent and Selective beta-Site Amyloid Cleaving Enzyme (BACE) Inhibitors: Part I-Inhibitor Design and Validation. J Med Chem 53(3): 951-965.

19. Turner III RT, Koelsch G, Hong L, Castanheira P, Ermolieff J, et al. (2001) Proteolytic Activation of Recombinant Pro-memapsin 2(Pro-

\section{ISSN: 2574-1241}

DOI: $10.26717 / B J S T R .2018 .11 .002140$

Archana $S$ Gurjar. Biomed J Sci \& Tech Res

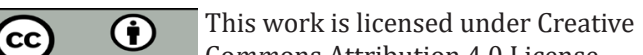

Submission Link: https://biomedres.us/submit-manuscript.php $\beta$-secretase) Studied with New Fluorogenic Substrates. J Biochemistry 40(39): 12450-12456.

20. Baxter E, Boyd R, Coats S, Jordan A, Reitz A, et al. (2006) J in WO Patent 17: 844 .

21. Qik Prop, version 3.0; Schrodinger, LLC: New York, USA.

22. Garino C, Pietrancosta N, Laras Y, Moret V, Rolland A, et al. (2006) BACE1 inhibitory activities of new substituted phenyl-piperazine coupled to various heterocycles: chromene, coumarin and quinoline. Bioorganic Med Chem Lett 16(7): 1995.

23. Ghose AK, Herbertz T, Hudkins RL, Dorsey BD, Mallamo JP (2012) Knowledge-Based, Central Nervous System (CNS) Lead Selection and Lead Optimization for CNS Drug Discovery. ACS Chem Neurosci 3(1): 50-68.

24. Sybyl version 8.1.1, Tripos International, St. Louis, Missouri, USA.

25. GOLD version 4.1.1, CCDC Ltd., UK.

26. Gurjar AS, Andrisano V, Simone AD, Velingkar VS (2014) Design, synthesis, in silico and in vitro screening of 1,2,4-thiadiazole analogues as non-peptide inhibitors of beta-secretase. Bioorganic Chemistry 57: 90-98.

27. Shoeb A, Popli SP, Dhar ML (1963) Journal of the Indian Chemical Society 40: 369.

28. Kornacker MG, Lai Z, Witmer M, Ma J, Hendrick J, et al. (2005) An inhibitor binding pocket distinct from the catalytic active site on human beta-APP cleaving enzyme. Biochemistry 44(34): 11567-11573.

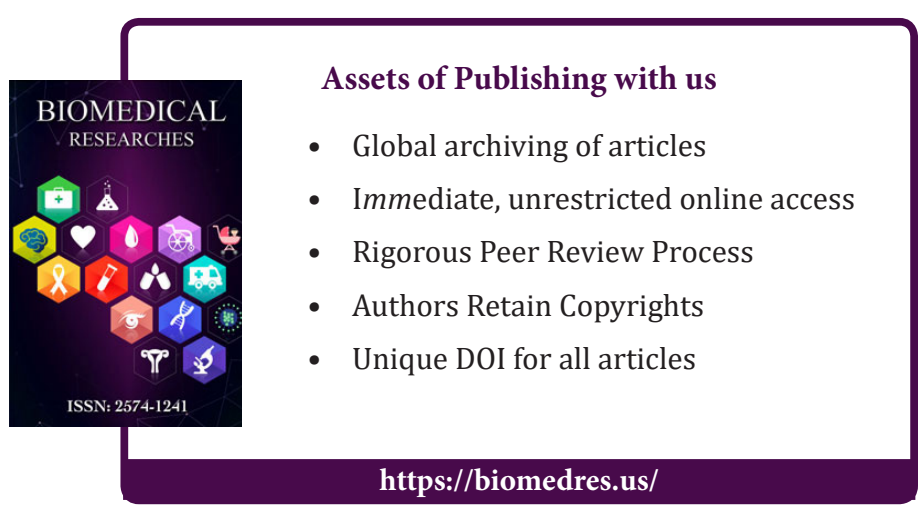

